\title{
ReSEARChArticle
}

\section{Effect of integrated nutrient management on growth, herb yield and quality of alfalfa during Rabi season under central dry zone of Karnataka}

\author{
Nagappa Desai, A.P. Mallikarjuna Gowda and T.S. Sukanya
}

\begin{abstract}
SUMMARY
The experiment was conducted to study the effect of integrated nutrient management on growth, herb yield and quality of alfalfa (Medicago sativa L.) at the farm field of Krishi Vigyan Kendra, Konehalli, Tiptur, Tumkuru district under Central dry zone (Zone-4) of Karnataka state during Rabi seasons. The results revealed that the maximum plant height at 30 DAS $(43.12 \mathrm{~cm})$, first $(85.63 \mathrm{~cm})$, second $(86.00 \mathrm{~cm})$, third $(92.10 \mathrm{~cm})$, fourth $(95.45 \mathrm{~cm})$, fifth $(92.30 \mathrm{~cm})$, sixth $(88.90 \mathrm{~cm})$ and seventh harvest $(86.79 \mathrm{~cm})$ during Rabi season was recorded, when plants were supplied with $50 \%$ RDF + $25 \% \mathrm{~N}$ through vermicompost + Rhizobium + PSB + VAM. The least plant height was recorded with the application of 10 t/ha $\mathrm{FYM}+100 \% \mathrm{~N}$ through FYM at $30 \mathrm{DAS}$ and all the harvests. The similar results were recorded the maximum number of branches and leaves per plant with application of the $50 \% \mathrm{RDF}+25 \% \mathrm{~N}$ through vermicompost + Rhizobium + PSB + VAM. The maximum fresh and dry herb yield per hectare was recorded at first (178.70 q and $26.30 \mathrm{q})$, second $(213.89 \mathrm{q}$ and $31.44 \mathrm{q})$, third (217.13 q and $31.94 \mathrm{q})$, fourth (218.98 q and $33.08 \mathrm{q})$, fifth (216.20 q and $31.81 \mathrm{q})$, sixth (208.33 q and $30.65 \mathrm{q})$ and seventh harvest (200.00 q and $29.40 \mathrm{q}$ ), respectively during Rabi season with the application of $50 \% \mathrm{RDF}+25 \% \mathrm{~N}$ through vermicompost + Rhizobium + PSB + VAM. Whereas, the lowest fresh and dry herb yield per hectare was recorded, when plants supplied with 10 t/ha FYM $+100 \% \mathrm{~N}$ through FYM at all the harvests. The pants received with 50 $\% \mathrm{RDF}+25 \% \mathrm{~N}$ through vermicompost + Rhizobium $+\mathrm{PSB}+\mathrm{VAM}$ has resulted maximum nitrogen content of plant at first (1.15\%), second (1.14\%), third (1.15\%), fourth (1.12\%), fifth (1.09\%), sixth (1.06\%) and seventh harvest (1.05\%) during Rabi season, which was at par with the application of $50 \% \mathrm{RDF}+25 \% \mathrm{~N}$ through poultry manure + Rhizobium + PSB + VAM at first and third harvests. The application of $10 \mathrm{t} / \mathrm{ha}$ FYM $+100 \% \mathrm{~N}$ through FYM recorded lowest nitrogen content of plant in at all the harvests. Therefore, $50 \% \mathrm{RDF}+25 \% \mathrm{~N}$ through vermicompost + Rhizobium + PSB + VAM may be recommended for commercial cultivation of alfalfa during Rabi season under central dry zone of Karnataka.
\end{abstract}

\section{MEMBERS OF THE RESEARCH FORUM}

Author to be contacted :

Nagappa Desai, Krishi Vigyan Kendra (UAS), Konehalli, Tiptur Taluk, Tumkuru (Karnataka) India

Email : agridesai@gmail.com

Address of the Co-authors:

A.P. Mallikarjuna Gowda, Department of Plantation, Spices, Medicinal and Aromatic Plants, College of Horticulture, UHS Campus, G.K.V.K., Bengaluru (Karnataka) India

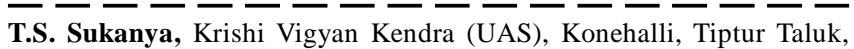
Tumkuru (Karnataka) India
Key Words : Alfalfa, Bio-fertilizers, Harvest, Nutrient, Ratoon crop, Season

\begin{abstract}
How to cite this article : Desai, Nagappa, Mallikarjuna Gowda, A.P. and Sukanya, T.S. (2018). Effect of integrated nutrient management on growth, herb yield and quality of alfalfa during Rabi season under central dry zone of Karnataka. Internat. J. Plant Sci., 13 (1): 171-179, DOI: 10.15740/HAS/IJPS/13.1/171-179.
\end{abstract}

Article chronicle : Received : 16.11.2017; Revised : 07.12.2017; Accepted : 21.12.2017 